\title{
ПОРІВНЯЛЬНИЙ АНАЛІЗ КІРЛІАНОГРАФІЧНОГО СВІТІННЯ БІОЛОГІЧНОЇ ТКАНИНИ 3 БІОХІМІЧНИМИ ПРОЦЕСАМИ
}

\author{
Л. А. Пісоцька ${ }^{1}$, Н. В. Глухова ${ }^{2}$, В. А. Повстяний ${ }^{1}$, Н. М. Євдокименко $^{3}$, \\ Г. П. Черненко \\ ДЗ «Дніпропетровська медична академія мОЗ України» ${ }^{1}$ \\ ДВНЗ «Національний гірничий університет»² \\ ДВНЗ «Український хіміко-технологічний університет» ${ }^{3}$
}

\begin{abstract}
Порівняли кірліанографічне зображення зразків та рідини ахілового сухожилка різного постморбідного періоду (від 5 годин до 22 діб) із показниками біохімічних досліджень в процесі аутолізу. Кірліанографію проводили на рентгенівській плівці. Використовували експериментальний прилад «РЕК 1» (м. Дніпропетровськ). Процес саморуйнування тканин сухожилка, як показали результати експериментів, мав циклічний характер змінення активності ферментів обміну амінокислот (АЛТ), вуглеводів (ЛДГ), нуклеотидів (сечова кислота, сечовина), вмісту загального білка та мікроелементів. Зміни площі засвітки та фрактальності кірліанограм крапель біологічної речовини в процесі аутолізу також мали циклічність з часом, що віддзеркалювало характер енергетичних змін за вмістом речовин взаємодії.
\end{abstract}

Ключові слова: кірліанографія, біологічна тканина, біохімія, аутоліз.

\section{СРАВНИТЕЛЬНЫЙ АНАЛИЗ КИРЛИАНОГРАФИЧЕСКОГО СВЕЧЕНИЯ БИОЛОГИЧЕСКИХ ТКАНЕЙ С БИОХИМИЧЕСКИМИ ПРОЦЕССАМИ}

\author{
Л. А. Писоцкая ${ }^{1}$, Н. В. Глухова ${ }^{2}$, В. А. Повстяный ${ }^{1}$, Н. М. Евдокименко ${ }^{3}$, \\ Г. П. Черненко

ГУ «Днепропетровская медицинская академия» ${ }^{1}$
ГВУЗ «Национальный горный университет» ${ }^{2}$
ГВУЗ «Украинский химико-технологический университет» ${ }^{3}$

\begin{abstract}
Сравнивали кирлианографические изображения образцов и жидкой части ахиллова сухожилия разного постморбидного периода (от 5 часов до 22 суток) с показателями биохимических исследований в процессе аутолиза. Кирлианографию проводили на рентгеновской пленке. Использовали экспериментальный прибор «РЕК 1» (г. Днепропетровск). Процесс самопереваривания (аутолиза) тканей сухожилия, как показали результаты экспериментов, имел циклический характер изменения активности ферментов обмена аминокислот (АЛТ), углеводов (ЛДГ), нуклеотидов (мочевая кислота, мочевина), содержания общего белка и микроэлементов. Изменение площади засветки и фрактальности кирлиановских изображений также имело цикличный характер по давности аутолиза, что ображало характер энергетических изменений по содержанию взаимодействующих веществ.
\end{abstract}

Ключевые слова: кирлианография, биологическая ткань, биохимия, аутолиз.

\section{COMPARATIVE ANALYSIS OF KIRLIANOGRAFIIA IMAGES GLOW OF BIOLOGICAL TISSUES WITH BIOCHEMICAL PROCESSES}

\author{
L. A. Pisotska ${ }^{1}$, N. V. Hlukhova ${ }^{2}$, V. A. Povstyanyi ${ }^{1}$, N. M. Yevdokymenko ${ }^{3}$, \\ H. P. Chernenko ${ }^{1}$ \\ State Establishment «Dnipropetrovsk Medical Academy of Health Ministry of Ukraine» ${ }^{1}$ \\ SHEI National Mining University ${ }^{2}$ \\ SHEI Ukrainian State University of Chemical Technology ${ }^{3}$
}

\begin{abstract}
Kirlian diagram samples Conducted. Achilles tendon dead people with various postmorbidnym period (from 5:0 until 22 days) and optoelectronics is part of the standard terms of the x-ray film developer. The results obtained were compared with biochemical indicators of the level of enzymes and content of degradation products of proteins, trace elements, derived from
\end{abstract}


the investigated samples. For kirlianograficeskih studies used an experimental device, RIVERS 1, developed by Ukrainian Scientific Research Institute of mechanical engineering technologies (Dnepropetrovsk). For mathematical processing of results using Matlab program.

The growing shortage of ATP causes the breach and termination of ion exchange, increases reactive oxygen generation, lipid peroxidation destroys cell membranes. The process of self digestion (autoliza) tissue tendons, as shown by the results of the experiments, had cyclical changes metabolism enzyme activity (ALT), carbohydrate (LDH), nucleotides, of total protein and micronutrients.

Conclusions. 1. Draws the attention of the cyclical changes in illumination from images of biological fluid droplets in the process autoliza, reflecting the cyclical energy processes associated with cycles of interacting substances referred to above.

2. Reduction of image Kirlian image drops biological fluids with prescription postmorbidity the time the fabric, represented a decrease of free water and increases the structure of the Crystal.

3. Conducted preliminary studies suggest line Kirlian luminescence of biological objects, belonging to the biophysical level of interactions in the biochemical processes occurring in them.

Key words: kirlianografia, biological tissue, biochemistry, autoliz.

Вступ. Не дивлячись на відкриття подружжям Кірліан ще в 40-х роках минулого століття світіння об'єктів живої та неживої природи в полі високої напруги, численні дослідження цього методу в галузі медицини в різних країнах, поширення кірліанографії для експрес-діагностики фізіологічного стану організму немає, що потребує подальшого вивчення ефекту світіння в сукупності з відомими методами доказової медицини. Єднання порозуміння біофізичних і біохімічних природних процесів, як проявів матерії фізичних явищ польового характеру та матерії хімічного обміну речовин, дозволяють зрозуміти фізіологічну значимість явища кірліан-світіння в природі для людини. Раніше нами були проведені дослідження зміни в біо-

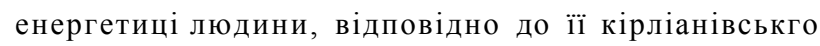
світіння, після вживання активованої води «РАДО» 3 утворенням перекису водню. Зміни в організмі були пов'язані 3 активністю біохімічних процесів на клітинному рівні, стан якого за дослідженнями доктора П. Мандела віддзеркалює кірліанівське світіння [2, 3]. Було також знайдено зв'язок між біоенергетикою зразків тканин ахілового сухожилка за їх кірліанівським зображенням та біохімічними показниками [1].

Мета роботи: порівняння кірліанографічних зображень зразків і рідини біологічної тканини 3 їх біохімічними дослідженнями в процесі аутолізу на прикладі ахілового сухожилка.

Матеріал та методи дослідження. Проводили кірліанографію зразків ахілового сухожилка померлих людей з різним післяморбідним періодом Т (від 5 годин до 22 діб) та їх рідину на рентгенівській плівці. Отримані результати порівнювали 3 біохімічними показниками рівня ферментів в них, продуктів розпаду білків та мікроелементів. Кірліанографічні дослідження проводили на екс- периментальному приладі «РЕК 1», розробленому Українським НДІ технологій машинобудування (м. Дніпропетровськ).

Для математичної обробки отриманих результатів використовували прикладне програмне забезпечення, котре реалізує виконання процедури бінаризації зображень за порогом яскравості, розрахунок площі засвітки та оцінку фрактальної розмірності (ФР).

Просторові процедури обробки зображень передбачають операції безпосередньо зі значеннями яскравості пікселів та можуть у загальному випадку бути описані на основі рівняння:

$$
g(x, y)=T[f(x, y)],
$$

де $f(x, y)$ - вхідне зображення; $g(x, y)$ - вихідне зображення після процедури обробки; $T$ - оператор, визначений у певній околиці точки $(x, y)$. Зазвичай у якості околиці використовується квадратна або прямокутна область, тобто підмножини зображення 3 центром у точці 3 координатами $(x, y)$. Найпростішим випадком $є$ використання оператору $T$ до околиці розміром $1 \mathrm{x} 1$, тоді $g$ залежить тільки від значення $f$ у точці $(x, y)$, тобто обробці підлягає один піксель. У такому випадку оператор Тназивають функцією градаційного перетворення, функцією перетворення інтенсивностей або функцією відображення, що аналітично описується як:

$$
s=T(r) \text {, }
$$

де $r$ та $\mathrm{s}$ - змінні, які відповідають значенням яскравості вхідного $f(x, y)$ та вихідного $g(x, y)$ зображень для кожної окремої точки $(x, y)$.

Функції градаційного перетворення використовуються для підвищення контрастності зображень, також для затемнення пікселів зі значенням яскравості меншим, ніж обране порогове значення $m$ та підвищенні яскравості для пікселів 3 яскравістю більшою, ніж $m$. При підсиленні контрасту зна- 
чення $r$ менші $m$ при наближенні до рівня чорного кольору стискаються у вузький діапазон s, для значень $r$ більших $m$ - навпаки. Бінаризація відбувається у граничному випадку, у результаті чого отримаємо двоградаційне бінарне зображення за певною пороговою функцією. Площа засвітки обчислюється для бінаризованого зображення.

Також операція бінаризації напівтонового растрового зображення є першим необхідним кроком для оцінки фрактальної розмірності (ФР). Метод оцінки ФР є операцією параметризації зображення, яка дозволяє оцінити характер самоподібності певного об'єкта або характеристик зафіксованого явища [4]. Для оцінки фрактальної розмірності бінаризованих зображень газорозрядного випромінювання використаний алгоритм box counting [5].

Отримані результати та їх обговорення. Постмортальний некроз тканин характеризується швидким зсувом $\mathrm{pH}$ в кислу сторону внаслідок їх денервації, а також порушення кровопостачання, що призводить до припинення аеробних окиснювальних процесів і посилення гліколізу, накопичення лактату. Наслідком цього є звільнення з лізосом всього комплексу літичних ферментів - катепсинів, глікозидаз, нуклеаз, фосфоліпаз, з лавиноподібним накопиченням кислих речовин; набрякання і лізис клітин - фіброцитів і фібробластів, деградація аморфної основної речовини сухожилка 3 розпадом фібрилярних білків, глікозаміногліканів, нуклеїнових кислот та нуклеотидів загиблих клітин. Зростає дефіцит АТФ, що супроводжується порушенням і зникненням іонного обміну, збільшується генерація активних форм кисню, перекисне окиснення ліпідів руйнує клітинні мембрани. Процес саморуйнування (аутолізу) тканин сухожилка, як показали результати експериментів, мав циклічний характер змін активності ферментів обміну амінокислот (АЛТ), вуглеводів (ЛДГ), нуклеотидів, вмісту загального білка і мікроелементів (табл. 1).

Реакції розпаду поліпептидів і реакції взаємодії їх продуктів мають характер конкуренції. Так як швидкість хімічних реакцій за законом діючих мас визначається концентрацією діючих речовин, при великій концентрації продуктів руйнування у зразків до 5 діб від часу біологічної смерті організму, коли домінують реакції розпаду, спостерігали збільшення біохімічної активності ферментів i похідних аутолізу білків. В подальшому, з часом переважають реакції їх взаємодії між собою, що апріорі призведе до спаду біохімічних показників, що ми спостерігали в експерименті. Подальше їх накопичення супроводжується ростом показників внаслідок їх взаємодії, після чого зменшення їх концентрації в досліджуваному розчині тканинної рідини призведе до їх зниження тощо. На представлених змінах інших біохімічних показників спостерігали аналогічні закономірності за часом.

Відомо, що активність функціональних груп залежить від молекулярної маси з'єднання (ММ). Чим вище ММ, тим активність нижча. Тому швидкості реакцій катаболізму речовин 3 різною ММ і взаємодії продуктів розпаду будуть різні, зберігаючи циклічний характер змін (табл. 1).

Таблиця 1. Результати біохімічних досліджень зразків із різним післяморбідним часом $\mathrm{T}$

\begin{tabular}{|c|c|c|c|c|c|c|c|c|c|c|c|}
\hline $\begin{array}{l}\text { T (годин, } \\
\text { діб) смер- } \\
\text { ті }\end{array}$ & $\begin{array}{c}\text { АЛТ, } \\
\text { од/л }\end{array}$ & $\begin{array}{l}\text { ЛДГ, } \\
\text { од/л }\end{array}$ & $\begin{array}{l}\text { Загальн. } \\
\text { білок, г/л }\end{array}$ & $\begin{array}{l}\text { Сечовина, } \\
\text { мкмоль/л }\end{array}$ & $\begin{array}{c}\text { Сеч. } \\
\text { кисл., } \\
\text { мкмоль/л }\end{array}$ & $\begin{array}{c}\mathrm{Na}, \\
\text { ммоль/л }\end{array}$ & $\begin{array}{c}\text { К, } \\
\text { ммоль/л }\end{array}$ & $\begin{array}{c}\mathrm{Ca}, \\
\text { ммоль/л }\end{array}$ & $\begin{array}{c}\mathrm{Fe}, \\
\text { ммоль/л }\end{array}$ & $\begin{array}{c}\mathrm{Cu}, \\
\text { ммоль/л }\end{array}$ & $\begin{array}{c}\mathrm{Zn}, \\
\text { ммоль/л }\end{array}$ \\
\hline До 24 год & 2 & 34 & 1,8 & 0,3 & 11,6 & 49,8 & 27,4 & 0,2 & 1,6 & 8,8 & 12,3 \\
\hline 24-27 год & 69 & 86 & 48,7 & 0,9 & 157,9 & 118,0 & 89,6 & 1,8 & 1,5 & 32,1 & 32,1 \\
\hline 3-5 діб & 246 & 135 & 41,6 & 1,4 & 923,4 & 88,3 & 98,5 & 1,8 & 4,8 & 22,5 & 25,8 \\
\hline 6-10 діб & 103 & 98 & 13,3 & 1,3 & 41,4 & 53,2 & 24,9 & 0,4 & 1,7 & 3,2 & 11,2 \\
\hline 11-20 діб & 65 & 165 & 27,1 & 0,9 & н/д & 104,0 & 103,4 & 1,8 & 0,5 & 33,9 & 31,2 \\
\hline біл. 20 діб & 0,3 & 157 & 11,3 & 1,6 & 158,0 & 204,0 & 43,2 & 2,0 & 2,5 & 32,1 & 29,4 \\
\hline
\end{tabular}

Світіння живих та неживих об'єктів у полі високої напруги, відоме як ефект Кірліан, зв'язане 3 випромінюванням ними фотонів в газовому розряді, при реакціях взаємодії речовин на квантовому рівні. У результаті процесу аутолізу, що спочатку має характер росту внаслідок прогресії «порушень мембран»у клітинах, хімічні реакції мають ланцюговий механізм 3 великою швидкістю. При цьому має місце високочастотне випромінювання оптичної та ультрафіолетової частин спектра. 
Останнє є «кірліанівським світінням», що фіксує рентгенівська плівка. 3 часом, у зв'язку 3 «виснаженням» ферментативних систем і розвитком анаеробного обміну, в глибині тканин змінюється спектр випромінювання із зсувом в інфрачервону частину із збільшенням відділення енергії тепла (дегенеративний тип випромінювання за П. Манделем).

Молекулярні реакції взаємодії речовин при цих механізмах аутолізу тканин 3 реактивом плівки відрізняються. При фотонній емісії реакції мають

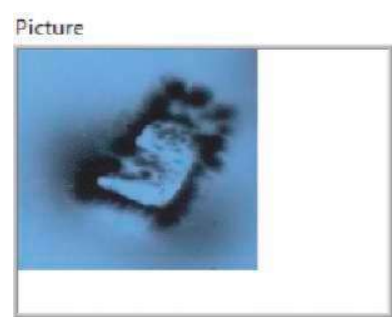

Площадь засветки 4764

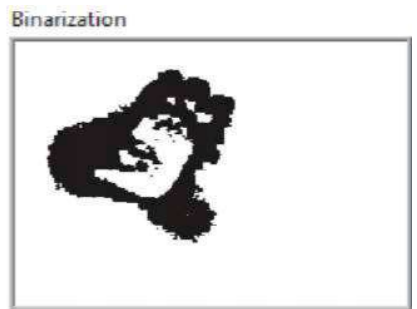

Т - 5-8 годин

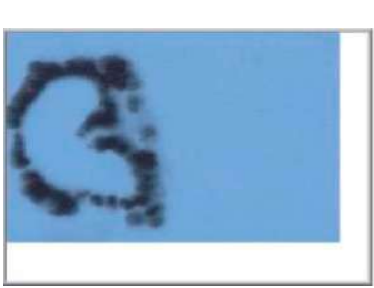

Площадь засветки

3451

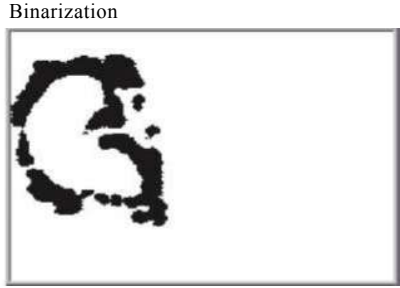

$$
\text { Т - 7-8 діб }
$$

ланцюговий характер i швидкість їх взаємодії змінюється циклічно, що на кірліанівському зображенні виглядає окремими поруч розміщеними стримерами в короні світіння. При збільшенні температури (анаеробний обмін речовин) швидкість реакцій взаємодії з реактивом плівки також збільшується, що посилює малюнок зображення, стримери в короні зливаються між собою. Згодом, при зменшенні реагуючих речовин, очікується різке зниження світіння з розривами в контурі корони, що ми і спостерігали (рис. 1).

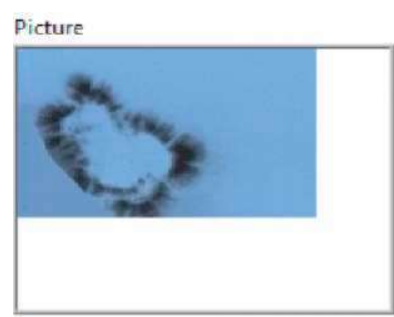

Binarization

Площадь засветки

1885

Т - 4-5 діб
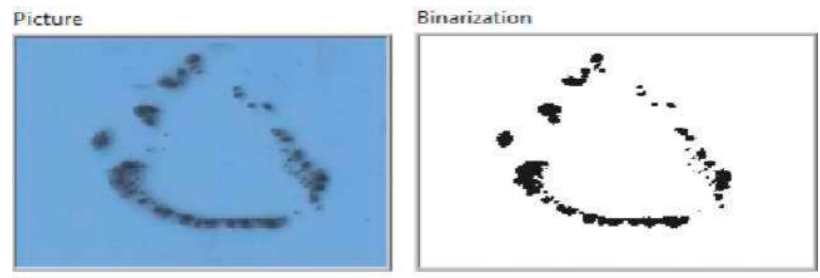

Площадь засветки

1389

Т - 22 дні

Puc. 1. Зображення кірліанівського світіння навколо фрагментів з різним Т.

На рисунку 2 наведено кірліанівське випромінювання рідини із зразків з різним Т.
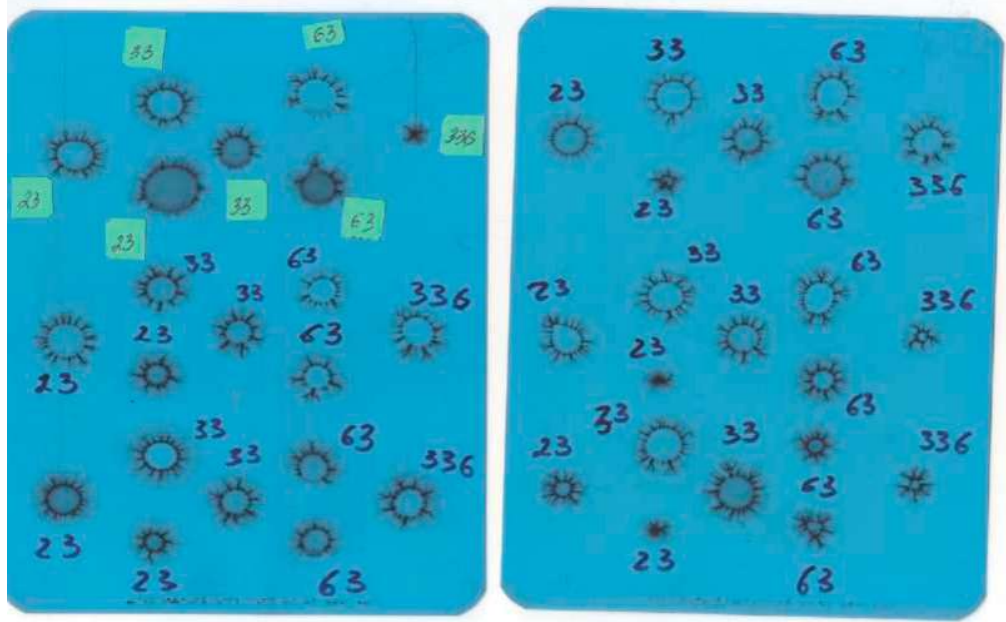

Puc. 2. Кірліанограми крапель рідини зразків тканини ахілового сухожилка. 
Таблиця 2. Кірліанограми крапель рідини зразків тканини ахілового сухожилка

\begin{tabular}{|c|c|c|c|c|c|c|c|c|}
\hline \multirow{3}{*}{$\begin{array}{l}\text { Номер } \\
\text { зразка }\end{array}$} & \multicolumn{8}{|c|}{ Параметри } \\
\hline & \multicolumn{2}{|c|}{23 (Т 5 годин) } & \multicolumn{2}{|c|}{33 (Т 4-5 діб) } & \multicolumn{2}{|c|}{63 (Т 7 діб) } & \multicolumn{2}{|c|}{336 (Т 3 доби) } \\
\hline & $\begin{array}{l}\text { площа } \\
\text { корони }\end{array}$ & $\Phi P$ & $\begin{array}{c}\text { площа } \\
\text { корони }\end{array}$ & $\Phi P$ & $\begin{array}{c}\text { площа } \\
\text { корони }\end{array}$ & $\Phi P$ & $\begin{array}{c}\text { площа } \\
\text { корони }\end{array}$ & $\Phi P$ \\
\hline 1 & 18992 & 1,77554 & 6764 & 1,57949 & 6156 & 1,5681 & 647 & 1,21482 \\
\hline 2 & 12892 & 1,68761 & 5502 & 1,59706 & 5108 & 1,5642 & 4206 & 1,49818 \\
\hline 3 & 16043 & 1,74873 & 8313 & 1,626 & 6178 & 1,5981 & 6567 & 1,59404 \\
\hline 4 & 7374 & 1,63466 & 8918 & 1,65243 & 7278 & 1,6347 & 6544 & 1,60016 \\
\hline 5 & 10833 & 1,68879 & 14850 & 1,73601 & 4809 & 1,5598 & 3036 & 1,52604 \\
\hline 6 & 5883 & 1,63075 & 14418 & 1,76066 & 5039 & 1,6017 & 3328 & 1,52869 \\
\hline 7 & 6822 & 1,61187 & 14719 & 1,7407 & 6007 & 1,5641 & & \\
\hline 8 & 1770 & 1,43996 & 9230 & 1,67298 & 6204 & 1,5898 & & \\
\hline 9 & 8959 & 1,65145 & 15401 & 1,74385 & 6934 & 1,6066 & & \\
\hline 10 & 1000 & 1,35675 & 16521 & 1,79927 & 6298 & 1,6113 & & \\
\hline 11 & 5502 & 1,59652 & 16796 & 1,77514 & 3709 & 1,5533 & & \\
\hline 12 & 1101 & 1,3797 & 16288 & 1,74876 & 3045 & 1,5096 & & \\
\hline Cep. ap. & 8097,58 & 1,6001 & 12310 & 1,70269 & 5563,75 & 1,5801 & 4054,66 & 1,49 \\
\hline СКО & 5769,72 & 0,1371 & 4199,66 & 0,07381 & 1262,27 & 0,0334 & 2267,57 & 0,14 \\
\hline
\end{tabular}

Можемо зробити висновок, що зразок 3 Т 5 год має середні за абсолютними величинами як площі корони світіння (ПКС), так і ФР, проте для нього була характерна велика розбіжність (середнє квадратичне відхилення) відносно середнього значення. Тобто параметри світіння нестабільні, що відображає динамічність аеробних біохімічних реакцій у перші післяморбідні години. Зразок із Т 4-5 діб характеризується максимальним середнім значенням ПКС та ФР, що відповідає максимальній біохімічній активності взаємодіючих речовин зруйнованих клітин. Для зразка 3 T 3 діб характерні мінімальні ПКС і значення ФР, що пов'язано 3 виснаженням продуктів аеробних процесів в тканинах $з$ ще низьким вмістом речовин аеробного обміну. Зразок з Т 7-8 діб має середні за абсолютними величинами показники світіння (невелика площа засвітки, середня серед всіх зразків ФР), йому притаманна найбільша стабільність

\section{Література}

1. Корреляция кирлианографических и биохимических характеристик на примере Ахиллового сухожилия / Н. М. Евдокименко, Л. А. Песоцкая, В. А. Повстяный, Н. В. Глухова // Валеологія: сучасний стан, напрямки та перспективи розвитку : тези допов. XIII міжнар. наук.практ. конф., 9-11 квітня 2015 р. - Харків, 2015. - Режим доступу: http://valeolog.net. характеристик світіння, що відображає анаеробний механізм обміну речовин із змінами частот фотонної емісії. Однаковий малюнок зображення відображає більшу схожість тканини із структурою кристалу, ніж води, на відміну від недавніх зразків за часом Т.

Висновки. 1. Циклічність зміни площі засвітки на кірліанограмах крапель біологічної речовини в процесі аутолізу з часом відображає циклічність енергетичних змін за вмістом речовин взаємодії.

2. Зниження варіабельності малюнка кірліанівських зображень крапель біологічної рідини з часом післяморбідного періоду тканини відображає зменшення вільної водної частини та збільшення в ній структури кристалу.

3. Наведені попередні дослідження дозволяють стверджувати про співвідношення кірліанівського світіння біологічних об'єктів, як біофізичного явища в них, із біохімічними процесами в тканинах.

2. Песоцкая Л. А. О некоторых биохимических аспектах кирлианографии / Л. А. Песоцкая, Н. М. Евдокименко // Медицина: достижения нового века : матер. IV науч.практ. конф. с междунар. уч., 27-28 февраля 2015 г., Гоа, Индия. - Академический журнал Западной Сибири. - 2015. - Т. 11, № 1 (56). - С. 17-18. - Режим доступу: www.elibrary.ru. 
3. Mandel P. Energetishe Terminalpunkt / P. Mandel. Diagnos-FRG : ESSEN, 1983. - 199 p.

4. Yuxin L. Image feature extraction and segmentation using fractal dimension / L. Yuxin, L. Yanda / IEEE. - 2007. - Vol. 2. - P. 975-979.
5. Long M. A Box-counting method with adaptable box height for measuring the fractal feature of images / M. Long, F. Peng // Radioengeneering. - 2013. - Vol. 22, № 1. P. 208-213. 